\title{
The Development of Condition Assessment for Heritage Building
}

\author{
Siti Nor Fatimah Zuraidi ${ }^{1 *}$, Mohammad Ashraf Abdul Rahman ${ }^{1}$, Zainal Abidin Akasah ${ }^{2}$ \\ ${ }^{1}$ Faculty of Technology Engineering, Universiti Tun Hussein Onn Malaysia, Edu-Hub Pagoh, 84600 \\ Muar, Johor, Malaysia \\ ${ }^{2}$ Faculty of Civil and Environmental Engineering, Universiti Tun Hussein Onn Malaysia, Parit Raja, \\ 86400 Batu Pahat, Johor, Malaysia
}

\begin{abstract}
This study examines the criteria and properties of the elements in the legacy of buildings. Using the Hierarchy Analysis Method (AHP), new instruments are developed based on the criteria and attributes that have been identified for the legacy building elements. The new instrument is given to industry professionals and academicians to get their opinions. This study shows the number of attributes of the score for the criteria. The results show that new instruments are developed and used as tools for assessing the elements of heritage building conditions. This new instrument can be proposed to the National Heritage Department to be used as a guideline for assessing the heritage buildings in the future.
\end{abstract}

\section{Introduction}

In the effort to extend the life of the heritage buildings in the country through the conservation of buildings, there is a tendency for the government to take over the building to be a memorial [1]. However, it raises the question of whether there are any guidelines on the assessment of the situation of heritage buildings in Malaysia's national memorial in maintaining heritage buildings as exhibition space related to the history of their leadership [2]. According to the case study and the literature review has found that there are heritage buildings are dilapidated, lost the characteristics of originality in design, architecture and building materials caused no heritage management and poorly maintained and modified on a scale that allows [1]. Such situations will indirectly accelerate the process of building damage occurring in a heritage building as well as destroying the original identity [2]. There are also some heritage buildings left without owners being known and left empty and unattended [2]. The weaknesses in managing the maintenance of heritage buildings have caused serious damage to building structures and fabrics [3]. The effects of these weaknesses have led to unsafe buildings to be occupied and the potential to be demolished as happened to the Bok House in Kuala Lumpur [1-2].

There is no standard for assessing the state of heritage buildings, various methods have been used in assessing [3]. Each method has different criteria. Each criterion will have another important stage. Considering the various methods of examination related to state

\footnotetext{
* Corresponding author: timi gee@yahoo.com
} 
building, new evaluation methods should be developed specifically to assess the condition of heritage buildings. This will ensure that the assessment of the situation is clearly distinguished from the inspection of the audit building and other buildings [4].

The purpose of this study is to find the best formulas for evaluating the condition of the heritage building. In this study, the instrument used is the technique of Analytical Hierarchy Process (AHP) and Delphi technique (TD) to obtain the opinion of the panel members. The objective of this study is to develop an element condition assessment instrument specifically for heritage buildings.

\section{Literature review}

Malaysia is very rich with heritage buildings that are priceless. Referring to the results of the study on the inventory of Malaysian heritage buildings carried out by the National Museum in 1992, it is estimated that about 35,000 pre-war buildings in 265 cities studied around the country should be preserved [2]. However, most of these heritage buildings are not well-preserved and most of them are in bad condition due to building damage factors [3]. It is even more unfortunate that these heritage buildings are being threatened with destruction as neglected by the original owners to be demolished on the demands of development as well as lack of community concerns in order to conserve heritage buildings [2-3]. However, it raises the question of whether there are any guidelines for assessing the condition of heritage buildings in Malaysia in maintaining heritage buildings as historical exhibition halls [3]. There are no guidelines creates a dispute on how to implement the process accordingly.

Assessment of the condition is an important aspect of effective maintenance planning [4]. Many studies have highlighted the factors that influence the quality of maintenance [3]. However, the number of researches focused on the evaluation of the very limited heritage of buildings [2-3]. The purpose of the assessment is to assess the state of the physical elements and building services and to assess the maintenance facilities requirements. The state assessment as a check and observation work on the outside and inside of the building, including the foundation, structure and mechanical system to identify the presence of any damage to the building and its components [5]. Meanwhile, the assessment of the situation is part of the investigation work on the construction and facilities of existing property with sufficient information to enable the value to advise on various problems that occur in the building [6]. Therefore, the organization of building and maintenance must have in-depth knowledge monitor their building conditions to prevent those defects and building failures. Inefficiencies building maintenance work systems may cause defects and damage to buildings [3].

Assessment of heritage building conditions is important as most of these buildings have been in existence for hundreds of years and have suffered much damage [7]. To ensure that the heritage buildings are safe and always in good condition, appropriate periodic inspections should be carried out to identify the current situation and to provide remedial action [5-6]. Thus, failure to check can contribute to the future failure of existing assets [8]. This study aims to develop a new instrument for assessing the state of the elements specific to the heritage buildings. The group of respondents involved is from industry professionals and academicians selected based on knowledge in the field of management and maintenance of the heritage. 


\section{Methodology}

The methodology used in this research is shown in Figure.1. This study using the AHP method and interview expert panel for checklist was developed from criteria and attributes in $[9,10,11$, and 12]. The criteria and attributes are summarized in Table 1. Using the checklist of the opinion of a panel of experts from two different backgrounds was solicited in structured interviews. The expert panel backgrounds are as follows:

i. Industry professional

ii. Academician

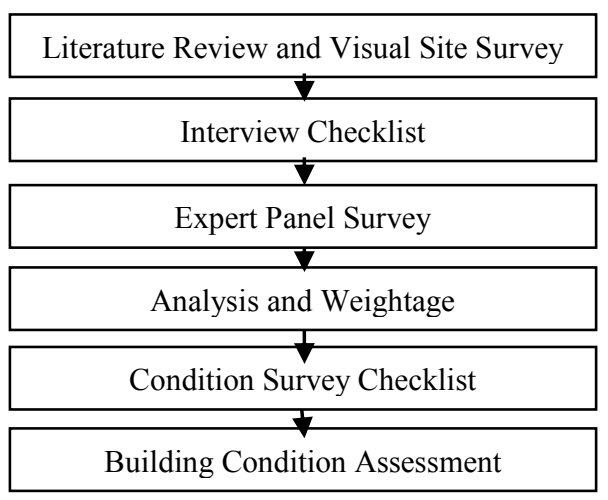

Fig. 1. Flow Chart of Process

The hierarchical structure in this study is the selection of elements of heritage building to the performance of building condition. Firstly, the goals need to set, the second is to determine the criteria and attributes of that goal. This study is choosing heritage building elements, the criteria include building a structure, building fabric, and building service. Lastly, the third level extracts from literature review and visual site survey to be selected in the set of attributes. The attribute includes foundation, column, beam, truss, stair, ceiling, floors, roof, windows, doors, internal and external walls, arch, electric, air condition, fire protection and sanitary. This all elements are important in the component of the heritage building.

Table 1. Criteria and Attributes to AHP Principle

\section{GOAL OF STUDY}

To Evaluate Element Condition In Heritage Building

\begin{tabular}{lll}
\hline & \multicolumn{1}{c}{ CRITERIA } \\
\hline Building Structure & \multicolumn{1}{c}{ Building Fabric } & Building Service \\
\hline & \multicolumn{1}{c}{ ATTRIBUTES } \\
& (Literature Reviews and Visual Site Survey) \\
\hline Foundation & Floor & Electric \\
Column & Interior Wall & Air Condition \\
Beam & External Wall & Fire Protection \\
Truss & Roof & Sanitary \\
Stair & Ceiling & \\
& Door & \\
& Window & \\
& Arch & \\
\hline & & \\
& & \\
& & \\
& & \\
& &
\end{tabular}


This process produces the element weight on goal achievement, so the highest weighted element has the priority of handling. The first step at this stage is to compile paired comparisons that are transformed into matrix form so that this matrix is called a paired comparison matrix. After the problem is decomposition, then there are two stages of assessment or comparing between elements for example comparison between criteria and comparison between options for each criterion. Comparison between criteria is intended to determine the weight for each criterion. Other than that, a comparison between options for each criterion is intended to see the weight of an option for a criterion. In other words, this assessment is intended to see how important an option is to be seen from certain criteria.

After providing a comparison of paired comparisons and calculating relative preferences, the final decision structure of the AHP model to evaluate the criteria and attribute of the element in the heritage building. According to AHP, the element heritage building which is the most important is for is a building structure is a foundation, for building fabric is a floor and for building service is electric. This result is expected because of the fact that all elements in heritage building are important to their function. The finding was processing using AHP manual calculation and set of weightage for each criterion and attributes respective was obtained. Table 2 shown the weightage for each criterion and attribute.

Table 2. The weightage of criteria and attribute

\begin{tabular}{cccc}
\hline \multicolumn{1}{c}{ Criteria } & Weightage & Attribute & Weightage \\
\hline \multirow{3}{*}{ Building Structure } & & Foundation & 0.458 \\
& \multirow{3}{*}{0.481} & Column & 0.221 \\
& & Beam & 0.207 \\
& & Truss & 0.076 \\
& Stair & 0.039 \\
\hline & Ceiling & 0.317 \\
& & Floor & 0.188 \\
Building Fabric & Internal Wall & 0.184 \\
& & External Wall & 0.121 \\
& \multirow{2}{*}{0.405} & Roof & 0.087 \\
& & Door & 0.050 \\
& & Window & 0.031 \\
& & Arch & 0.021 \\
\hline \multirow{3}{*}{ Building Service } & Electric & 0.525 \\
& & Air Condition & 0.279 \\
& & Fire Protection & 0.139 \\
& & Sanitary & 0.057 \\
\hline
\end{tabular}

The hierarchical process analysis is one of the methods that use hierarchical structures to represent problems and generate preferences based on consumer considerations [13]. The pairwise comparison method from Saaty has been used in this study by referring to the differences between criteria, relative importance and setting the scale between 1 to 5 , where 5 signifying optimal condition and 1 signifying critical conditions as in Table 3. 
Table 3. Grade assessment

\begin{tabular}{cccl}
\hline Grade & Inspection Scale & & \multicolumn{1}{c}{ Description } \\
\hline 1 & Very Poor (VP) & • & Critical damage, not functioning as agreed service level \\
& & - & Very critical, not functioning, risky to safety and health \\
\hline 2 & Poor (P) & - & $\begin{array}{l}\text { Major or minor damage, critical, not functioning as agreed } \\
\text { service }\end{array}$ \\
3 & Fair (F) & - & $\begin{array}{l}\text { Major defect, moderate condition, still can be functioning with } \\
\text { supervision }\end{array}$ \\
\hline 4 & Good (G) & - & Minor defect, Good condition, performing as intended \\
\hline 5 & Very Good (VG) & - & As New, No Defect, Performing as intended \\
\hline
\end{tabular}

Then, the analysis of defect findings connects the defective element for building conditions and the level of priority assessment as shown in Table 4.

Table 4. Priority assessment

\begin{tabular}{ccl}
\hline Condition & Scale & \multicolumn{1}{c}{ Description } \\
\hline 1 & Replacement & $\begin{array}{l}\text { Defect/damage or replacing of missing part of the } \\
\text { element }\end{array}$ \\
\hline 2 & Rehabilitation & Damage of element \\
\hline 3 & Repair & Major repair and replacement \\
\hline 4 & Routine & Minor repair \\
\hline 5 & Normal & Minor servicing \\
\hline
\end{tabular}

\section{Results and findings}

After getting the weightage for each criterion and attributes such as Table 2, new instruments have been developed such as table 7 below and used to determine the condition of heritage buildings. This new instrument will be used to facilitate the study to evaluate the situation of heritage buildings during a case study conducted at the site. The data obtained from structured interviews and expert panel opinion survey was analyzed using AHP with the help of the manual calculation. The score to obtain an element building condition level can be referred to in Table 5 .

Table 5. Element Building Condition Level

\begin{tabular}{cc}
\hline Inspection Scale & Score \\
\hline Very Poor & 0 to 1.999 \\
\hline Poor & 2 to 2.999 \\
\hline Fair & 3 to 3.999 \\
\hline Good & 4 to 4.999 \\
\hline Very Good & 5.000 \\
\hline
\end{tabular}

The rating for evaluation of the condition building also relates to the scale of actions and types of maintenance as shown in Table 6. 
Table 6. Maintenance Action

\begin{tabular}{ccl}
\hline Priority & Scale & \multicolumn{1}{c}{ Description } \\
\hline 1 & Replacement & $\begin{array}{l}\text { Critical/ serious defects/damages, needs for urgent, refer to expert } \\
\text { detail inspection/expert judgment }\end{array}$ \\
\hline 2 & Rehabilitation & $\begin{array}{l}\text { Critical/serious defects /damages, needs for urgent and immediate } \\
\text { repairs }\end{array}$ \\
\hline 3 & Repair & Major defects/damages, needs for major repairs and replacement \\
\hline 4 & Routine & $\begin{array}{l}\text { Minor defects/damages, needs for monitoring, repairs, replaced to } \\
\text { prevent serious defect/damages }\end{array}$ \\
\hline 5 & Normal & No defect or damages, element/component well maintained \\
\hline
\end{tabular}

Based on Table 2, the weightage for each criterion and attributes have been obtained and the checklist has been developed. Additionally, new instruments are developed and used as tools for assessing the elements of heritage building conditions in case studies. The categories of circumstances used, it is important that they are clear and data collectors are well trained to ensure consistency and reliability [14]. The observation of an assessor was recorded and graded based on 1 to 5 scales. The result from the condition survey was calculated by multiplying the assessment grade (refer to Table 3 ) with the global weightage of each attribute and subsequently the weightage of each criterion. The data were obtained and analysed using the new instrument of element condition assessment for the heritage building. The score in Table 7 for every three criteria and fourteen attributes was totalled to obtain the building condition assessment for the heritage building.

Table 7. Calculation for case study scenario A

\begin{tabular}{|c|c|c|c|c|c|c|c|c|c|c|}
\hline \multirow{2}{*}{\multicolumn{3}{|c|}{$\begin{array}{l}\text { Grade Assessment (A) } \\
\text { Criteria 1: Building } \\
\text { Structure (B1) } \\
\text { (Weightage : } 0.481)\end{array}$}} & \multirow{3}{*}{$\begin{array}{c}\begin{array}{c}\text { Weightage } \\
\text { of } \\
\text { Attributes }\end{array} \\
0.458 \\
\end{array}$} & \multirow{3}{*}{$\begin{array}{c}\text { VG } \\
5 \\
\sqrt{ } \\
\end{array}$} & \multirow{3}{*}{$\begin{array}{c}\mathrm{G} \\
4 \\
\end{array}$} & \multirow{3}{*}{$\mathbf{F}$} & \multirow{3}{*}{$\mathbf{P}$} & \multirow{3}{*}{$\begin{array}{l}\mathrm{VP} \\
1 \\
\end{array}$} & \multirow{3}{*}{$\begin{array}{c}\begin{array}{c}\text { Global } \\
\text { Weightage } \\
\text { (C) }\end{array} \\
0.220 \\
\end{array}$} & \multirow{3}{*}{$\begin{array}{c}\begin{array}{c}\text { Total of } \\
\text { Attribute } \\
(\mathbf{A} \times \mathbf{C})\end{array} \\
1.100 \\
\end{array}$} \\
\hline & & & & & & & & & & \\
\hline \multirow{5}{*}{ 紊 } & $\mathrm{A} 1$ & Foundation & & & & & & & & \\
\hline & $\mathrm{A} 2$ & Column & 0.221 & & $\sqrt{ }$ & & & & 0.106 & 0.424 \\
\hline & $\mathrm{A} 3$ & Beam & 0.207 & $\sqrt{ }$ & & & & & 0.099 & 0.495 \\
\hline & A4 & Truss & 0.076 & $\sqrt{ }$ & & & & & 0.037 & 0.185 \\
\hline & A5 & Stair & 0.039 & & $\sqrt{ }$ & & & & 0.019 & 0.076 \\
\hline \multicolumn{10}{|c|}{ Total of attributes score for criteria: } & 2.280 \\
\hline \multirow{2}{*}{\multicolumn{3}{|c|}{$\begin{array}{l}\text { Criteria 2: Building } \\
\text { Fabric (B2) } \\
\text { (Weightage:0.405) }\end{array}$}} & \multirow{2}{*}{$\begin{array}{c}\text { Weightage } \\
\text { of } \\
\text { Attributes }\end{array}$} & VG & $\mathbf{G}$ & $\mathbf{F}$ & $\mathbf{P}$ & $\mathbf{V P}$ & \multirow{2}{*}{$\begin{array}{c}\text { Global } \\
\text { Weightage }\end{array}$} & \multirow{2}{*}{$\begin{array}{c}\text { Total of } \\
\text { Attribute } \\
(\mathrm{A} \times \mathrm{C}) \\
\end{array}$} \\
\hline & & & & 5 & 4 & 3 & 2 & 1 & & \\
\hline \multirow{8}{*}{ 总 } & B1. & Floor & 0.317 & & $\sqrt{ }$ & & & & 0.035 & 0.140 \\
\hline & $\mathrm{B} 2$. & Interior Wall & 0.188 & & $\sqrt{ }$ & & & & 0.128 & 0.512 \\
\hline & B3. & External Wall & 0.184 & & & $\sqrt{ }$ & & & 0.076 & 0.228 \\
\hline & B4. & Roof & 0.121 & & & $\sqrt{ }$ & & & 0.075 & 0.225 \\
\hline & B5. & Ceiling & 0.087 & & $\sqrt{ }$ & & & & 0.049 & 0.196 \\
\hline & B6. & Door & 0.050 & & $\sqrt{ }$ & & & & 0.020 & 0.080 \\
\hline & B7. & Window & 0.031 & & & $\sqrt{ }$ & & & 0.013 & 0.039 \\
\hline & B8. & Arch & 0.021 & & $\sqrt{ }$ & & & & 0.009 & 0.036 \\
\hline
\end{tabular}




\begin{tabular}{|c|c|c|c|c|c|c|c|c|c|c|}
\hline \multirow{3}{*}{\multicolumn{3}{|c|}{$\begin{array}{l}\text { Criteria 3: Building } \\
\text { Service (B3) } \\
\text { (Weightage: 0.114) }\end{array}$}} & \multirow{4}{*}{$\begin{array}{c}\begin{array}{c}\text { Weightage } \\
\text { of } \\
\text { Attributes }\end{array} \\
0.525\end{array}$} & \multicolumn{6}{|c|}{ Total of attributes score for criteria: } & \multirow{3}{*}{$\begin{array}{c}1.456 \\
\text { Total of } \\
\text { Attribute } \\
(\text { A x C) }\end{array}$} \\
\hline & & & & VG & G & $\mathbf{F}$ & $\mathbf{P}$ & VP & \multirow{2}{*}{$\begin{array}{c}\begin{array}{c}\text { Global } \\
\text { Weightage }\end{array} \\
\end{array}$} & \\
\hline & & & & 5 & 4 & 3 & 2 & 1 & & \\
\hline \multirow{4}{*}{ 总 } & $\mathrm{C} 1$. & Electric & & & & $\sqrt{ }$ & & & 0.060 & 0.180 \\
\hline & $\mathrm{C} 2$. & Air Condition & 0.279 & $\sqrt{ }$ & & & & & 0.032 & 0.160 \\
\hline & $\mathrm{C} 3$. & Fire Protection & 0.139 & $\sqrt{ }$ & & & & & 0.016 & 0.080 \\
\hline & $\mathrm{C} 4$. & Sanitary & 0.057 & & $\sqrt{ }$ & & & & 0.006 & 0.024 \\
\hline \multicolumn{10}{|c|}{ Total of attributes score for criteria: } & 0.444 \\
\hline \multicolumn{7}{|c|}{ Total All Final Score of Criteria } & \multicolumn{4}{|c|}{4.180} \\
\hline \multicolumn{7}{|c|}{ Element Building Condition Level } & \multicolumn{4}{|c|}{ Good } \\
\hline \multicolumn{7}{|c|}{ Priority for Maintenance Action } & \multicolumn{4}{|c|}{ Routine } \\
\hline
\end{tabular}

According to the priority vector is the primary eigenvector of the matrix, therefore the priority is to calculate the pairwise comparison by using the AHP manual calculation by the eigenvector method. In this case study, the highest priority was given to building structures with 0.481 , building fabric with 0.405 and building services with 0.114 of their respective influence (Table 7).

The table also shows attribute ranking is changed when the importance of foundation over to all attribute in building a structure. Foundation has the highest priority with 0.458 respect to the building structure. While the other attribute show, a column with 0.221 , beam with 0.207 , truss with 0.076 and the lowest is stair with 0.039 . The ranking of attributes is as follows: foundation, column, beam, truss, and stair. In addition, the highest priority for building fabric criteria is a floor with 0.317 , an internal wall with 0.188 , an external wall with 0.184 , roof with 0.121 , ceiling with 0.087 , door with 0.050 , and window with 0.031 and last is an arch with 0.021 . The figure shows how attribute ranking is changed when the importance of the floor over to all attribute in building fabric. The ranking of attributes is as follows: Floor, interior wall, external wall, roof, ceiling, door, window, and arch.

Other than that, building service is described qualitatively, by words. The comparisons of the building service with respect to the criteria and attribute. It can be seen that electric have the highest priority of 0.525 . The medium priorities are air condition with 0.279 and fire protection with 0.139 and the lowest is sanitary with 0.057 . The attribute ranking is changed when the importance of electric over to all attribute in building service. The ranking of attributes is as follows: electric, air condition, fire protection and sanitary. All criteria and attribute is influence from each of them. The consistency ratio $(C R)$ indicates an acceptable level of inconsistency.

The finding of this study shows the number of attributes of the score for the criteria. For building structure criteria the number of attributes of the score is 2.280 , while the building fabric criteria of the total attribute of the score are 1.456 and the last criteria for service building the total attribute score is 0.444 . In conclusion, Scenario A has an overall score of 4.180, this shows that the condition of the building in good condition. Therefore, based on Table 6 the scale of action and the type of maintenance, Scenario A has achieved priority 4 and the scale of action is routine. The action scale for Scenario A needs to be done as scheduled maintenance action requirements such as monitoring, repair, replacement to prevent serious defects or damage. 


\section{Conclusion}

A building condition assessment model was generated using the method of AHP. Criteria decisions are summarized from the analysis according to the importance of criteria and attributes of the heritage building elements. Overviews of this model are as of Table 7. This model is made for the evaluation process to determine the condition of the building heritage that starts by defining a hierarchy of AHP, compare and evaluate the equivalence criteria and weighting for each attribute. Heritage building condition assessment model developed has formed three main criteria and seventeen attributes that connect alternatively to the overall goal. Alternatives that are used to determine whether the condition level of heritage buildings are in a very good, good, fair, poor and very poor.

This research was supported by the MyBrain15, the Office for Research, Innovation, Commercialization and Consultancy Management (ORICC) and Centre of Graduate Studies, University Tun Hussein Onn Malaysia, for making this publication possible.

\section{References}

1. S. N. F. Zuraidi, M. A. A. Rahman, \& Z. A. Akasah, Current Issues and Challenges of the Future In Heritage Building Maintenance at Malaysia: Literature Review, Journal of Humanities, Language, Culture and Business, Vol. 1(4), pp. 13-21 (2017)

2. M. A. A. Rahman, Z. A. Akasah \& S. N. F. Zuraidi, An Analysis of Current Demographic Trends of Maintenance Personnel of A Heritage Buildings in Malaysia, International Journal of Advanced Science Engineering Information Technology, Vol.2 (2), (2012)

3. S. N. F. Zuraidi, M. A. A. Rahman, \& Z. A. Akasah, Important Criteria for Measuring Heritage Building Condition. Journal of Built Environment, Technology, and Engineering, Vol. 2 (March), Vol. 2(3), 79-83. (2017)

4. A. Straub, Dutch Standard for Condition Assessment of Buildings. Structural Survey, Vol. 27(1), 23-35. (2009)

5. PWD. Manual Pengurusan Aset Kerajaan (MPAM). Kuala Lumpur, Malaysia: Public Work Department. (2009)

6. PWD, Building Condition Inspection for Existing Building. Kuala Lumpur, Malaysia: Public Work Department. (2013)

7. S. N. F. Zuraidi, M. A. A. Rahman, \& Z. A. Akasah, Measuring the Important Element of Defects in the Heritage Building. Management, Vol. 2(6), 73-83. (2017)

8. S. Yacob, A. S. Ali, \& A. Y. C. Peng, Building Condition Assessment: Lesson Learnt from Pilot Projects. In MATEC Web of Conferences, Vol. 66, p. 00072. (EDP Sciences, 2016)

9. W. K. Chow, Proposed Fire Safety Ranking System EB-FSRS for Existing High Rise Non-Residential Buildings in Hong Kong, ASCE Journal of Architectural Engineering, Vol. 8, No. 4, pp. 116-124. (2002)

10. Jr. Watts, J.M. \& M.E Kaplan, Fire Risk Index for Historic Buildings, Fire Technology, Vol.37, p.p.167-180, 2001. (2001) 
11. C. M. Zhao, S. M. Lo, J. A. Lu, \& Z. Fang, A Simulation Approach for Ranking of Fire Safety Attributes of Existing Buildings, Fire Safety Journal Vol 39(7), Pages 557-579. (2004)

12. S. N. F. Zuraidi, M. A. A. Rahman, \& Z. A. Akasah, Kriteria Penting Untuk Mengukur Keadaan Bangunan Warisan. Malaysian Journal of Social Sciences, Vol. 1(1), 92-102. (2018)

13. T. L. Saaty, Decision Making With the Analytic Hierarchy Process. International journal of services sciences, Vol. 1(1), 83-98. (2008)

14. T. J. Pitt. Data requirements for the prioritization of predictive building maintenance. Facilities, Vol. 15(3/4), 97-104. (1997) 